\title{
THE IMPLICATURE OF TEMBANG GAMBUH IN SERAT WEDHATAMA AND ITS SIGNIFICANCE FOR THE SOCIETY
}

\author{
Edy Tri Sulistyo*
}

\begin{abstract}
ABSTRAK
Kajian ini bertujuan untuk menemukan makna yang tersirat dalam naskah tembang Gambuh karya KGPAA Mangkunagara IV dalam Serat Wedhatama dan kebermaknaannya bagi masyarakat. Penuturan naskah tersebut terdiri 25 bait, namun kajian ini dibatasi pada bait yang berkaitan dengan sembah. Kajian dilakukan dengan menggunakan paradigma kualitatif, yang ditempuh deskriptif studi kasus tunggal terpancang. Data dihimpun dari sumber informan, tempat dan peristiwa serta dokumen/arsip atau kepustakaan. Validitas data digunakan trianggulasi data. Data dianalisis dengan model analisis pragmatik. Hasil temuan berdasarkan kajian pragmatik pada naskah tembang Gambuh yang dominan menunjukkan implikatur berkaitan dengan sembah raga, sembah cipta, sembah jiwa, dan sembah rasa. Adapun makna dari keempat sembah tersebut bagi masyarakat yakni sebagai peringatan dan pendidikan moral yang memiliki arti penting bagi seseorang untuk melakukan pendekatan kepada Allah swt dengan cara melaksanakan peribadatan yang telah dituntunkan.
\end{abstract}

Kata kunci: implikatur, pendidikan moral, sembah cipta, sembah jiwa, sembah raga, sembah rasa, serat Wedhatama, Tembang Gambuh

\begin{abstract}
This study was aimed to discover the meanings implied in the texts of Tembang Gambuh written by KGPAA Mangkunagara IV in his Serat Wedhatama as well as its significance for the society. The texts were originally composed of 25 stanzas, but this study was limited to those associated with sembah (worship). This study employed qualitative paradigm which was conducted by using an embedded-case-study research design. Data was collected from informants, places and events as well as documents/archives or library sources. The validity of the data was tested using the data triangulation. The data was then analyzed by using a model of pragmatic analysis. The findings based on the pragmatic analysis suggested that the dominant implicatures in the Tembang Gambuh in relation to sembah were sembah raga (worship by physical conduct), sembah cipta (worship by controlled/mind conduct), sembah jiwa (spiritual/soul worship), and sembah rasa (worship beyond rituals). For the society, these four types of worship can serve as a warning and moral education that have significant values for someone to draw closer to God by performing worship in accordance to the guideline.
\end{abstract}

Keywords: implicature, moral education, sembah cipta, sembah jiwa, sembah raga, sembah rasa, serat Wedhatama, Tembang Gambuh

\footnotetext{
* Faculty of Education and Teacher Training, Universitas Sebelas Maret, Surakarta
} 


\section{INTRODUCTION}

Tembang Gambuh is part of KGPAA Mangkunagara IV's speech in Serat Wedhatama. This Tembang (Javanese Song) is comprised of 25 stanzas (R.Ng. Satyopranowo and KRT. Sarjono Darmosarkoro, 2000:iii, Harmanto Bratasiswara, 2002:895; Ardani, 1995:38; Anjar Any, 2001:29; Simuh, 2002:253). As a classic work of literature, Serat Wedhatama (Supreme Wisdom) contains didactic values which idealize moral values or characters in Javanese culture as an adhiluhung (sublime) work (Pamberton, 1994:115; Anjar Any, 2001:5). However, it is contrary to the current reality. Almost every day, the mass media report cases of rape, murder, injustice, corruption, fraud, and the like. Based on these pathetic life events, the public need to be exposed to moral education so hopefully they do not fall into behaviors which are injurious to either themselves or others.

In relation to the above background, this study was aimed to reveal the meanings contained in the texts of Tembang Gambuh and hopefully it can give enlightenment to the society. Speeches uttered in the Tembang Gambuh are interesting to review because their meanings are very prominent in association with worship (drawing closer to Allah (swt) which means remembering Him at all times).

This study applied a pragmatic qualitative approach which was conducted by using an embedded-case-study research design. Data was collected from informants, places and events, as well as documents/archives or library sources. The validity of the data was tested using the data triangulation, a method to guide the researcher in collecting similar/particular data whereby a variety of different data sources must be used (Sutopo, 2006:93). The data was then analyzed by means of a pragmatic model, i.e. analyzing a language under the considerations of context in addition to paying attention to the syntax (the arrangement of words and phrases to create well-formed sentences in a language) and semantics (the meanings of words and phrases in language) (Hamid Hasan, 1993: 20). At the end of this analysis, a synthesis was done to draw a conclusion as a result of the study.

\section{THE MEANING OF SEMBAH (WORSHIP) AND ITS IMPLICATURE}

In the introduction of this paper, it has been stated that the Tembang Gambuh texts in Serat Wedhatama contain teachings related to sembah (worship). It can be shown in the following stanza.

Samêngko ingsun tutur

Sêmbah catur supaya lumuntur

Dhihin: raga, cipta, jiwa, rasa, kaki

Ing kono lamun tinêmu

Tandha nugrahaning Manon

'Now I beseech you'

'Four types of worship'

'Worship by the body, mind/heart, soul, and sense, my son'

'Whereby, If succeed, you can see'

'Signs of God's grace'

(Speech 1, source: R.Ng. Satyapranawa, and KRT. Sarjana Darmasarkara, 2000).

This stanza and the next ones were expressed in Javanese and then translated into English. This is in accordance with the initial purpose of the speech (in form of poem) which was intentionally delivered by the creator for the descendants of Kings in Java. Even, the poem was typically sung to make it listenable and make its meaning easy to catch. In the subsequent development, however, the poem was received well by the community at large. This is in accordance with Aris Munandar's opinion in Jurnal Humaniora (2013:92) that the use of Javanese language in communication in the community can be delivered orally or in writing.

The prominent utterance in the Canto of Gambuh particularly in the above stanza (speech 1) is 'sêmbah catur supaya lumuntur' (four types of worship you shall conduct) and 'dhihin: raga, cipta, jiwa, rasa, kaki' (worship by the body, mind, soul, and sense, my son). The advice given is the need for imitating and implementing sembah (worship), i.e. the four types of worship. If implemented well, they can provide a blessing for life. What is meant by the word sembah (worship) here is not like a homage paid by the people to 
their king, but an act to earnestly appreciate and utilize the gift from God. In this sense, worship can be divided into two types, namely physical worship and spiritual worship. Physical worship consists of five objects including worship to parents, worship to the parents-in-law, worship to older brothers, worship to the leader, and worship to the teacher. In contrast to physical worship, spiritual worship only requires worship to God Almighty.

A brief explanation of the meaning of physical worship is as follows. First, worship to the biological parents. To the biological parents, a child shall do this worship, in the sense that he/ she is obliged to respect and devote him/herself to them because they are the intermediaries for the existence and the birth of a child. For nine months, the fetus is inside the mother's womb. We can see how affectionate the parents in the care of the fetus, the birth, until the process to nurture. Considering the parents' hard work and affection, so it is an obligation for every child to worship them. Moreover, the parents' prayer for a child will be the priceless provision at the end of the day. Second, worship to the parents-in-law. The same as biological parents, the parents-inlaw shall also be respected and loved. In relation to the affinity of husband and wife (marriage), the parents-in-law are the ones who are instrumental in the procession.

Third, respect and worship to older brothers are also deemed necessary because (1) if the biological parents are dead, the ones who are responsible as the successor are them; (2) older brothers are born first, so they shall be respected; (3) older brothers have more life experiences too, so they shall be respected. Fourth, respect and worship to the leader, on the grounds that (a) a leader is seen as a person-in-charge in a community or country; (b) a leader who provides protection and safety for humans is beyond the parents themselves; (c) a leader provides welfare, sufficient food and clothing for the people.
Fifth, respect and worship to the teacher. This is also obliged and necessary because teacher is a person who sincerely has given knowledge, instruction, guidance, coaching to students in order to establish their independence. Paying respect to teacher is also a sign of gratitude and appreciation to the parents who are very instrumental in children's education. On the other hand, the spiritual worship is the main purpose of someone's life in this world, because at the end of life, people will go into the new world hereafter. If someone believes this, then someone will surely conduct spiritual worship. In this case, all religions teach how to perform spiritual worship. For example, in Islam, someone doing spiritual worship are obliged to perform the ritual prayers (salat) five times a day and night, and even then coupled with salat sunnah (optional prayers). It has been stated above that in this stanza, there are four types of worship that should be performed. The description of the four types of worship are as follows.

First, sêmbah raga (worship by the bodyrelated to physical conduct). The sêmbah raga tries to do deeds that lead to good/holy actions. The physical worship is here performed when someone will start a sêmbahyang (prayer) started with ablution by water, and usually done five times continuously every day, an in accordance with the rules that have been outlined. For example, in Islam, starting a ritual prayer must be preceded by wudlu (ablution by water); in the Christian religion, this is called a bath of water (baptism), while in Hinduism and Buddhism, it is done by sprinkling holy water.

Second, sêmbah cipta (worship by the mind -related to controlled conduct). The sêmbah cipta is performed by always learning to condition the mind to always be serene (cleansing the mind from misleading delusion).

Third, sêmbah jiwa (worship by the soulrelated to spiritual conduct). The sêmbah jiwa is performed by always being cautious to everything someone will do. 
Fourth, sêmbah rasa (worship by the sense). The sembah rasa is performed by always remembering the true rules of life (outlined by religion).

The implicature of speech in this stanza is that if someone has been able to find or implement the fourth types of worship, he/she has found grace or received guidance from God. People who receive guidance are those who have begun to be aware of the deficiencies or sins they did in the past, then surrender to God.

In order to more clearly comprehend the speech in the form of advice as described above, then the next stanza in Tembang Gambuh of Serat Wedhatama below is presented since it is also associated with worship.

\section{Sêmbah raga puniku}

Pakartiné wong amagang laku

Sêsuciné asarana saking warih

Kang wus lumrah limang wêktu

Waktu wataking wêwaton

'Worship by the body is'

'The act of a person being practicing'

'Ablution by water'

'Commonly done to perform the five-time prayers'

'Time is the nature of the rules'

(Speech 2, source: R.Ng. Satyapranawa, and KRT. Sarjana Darmasarkara, 2000).

The prominent utterances in this stanza of the Canto of Gambuh (speech 2) are sêmbah raga puniku pakartiné wong amagang laku which means meaning the act to purify parts of the body using water, in addition to beneficial for health and neatness. Health is essential for human life. Once someone is sick, he/she will certainly face difficulties in carrying out tasks/obligations. Purification by water (wudlu) is an act to be done by a Muslim before doing formal prayers, either mandatory (wajib) or optional (sunnah) in the attempt to get closer to Allah (swt).
As mandated by Sharia/Principles or as taught by the Prophet Muhammad, the acts of performing wudlu includes: (1) Intention of performing wudlu; the Prophet Muhammad PBUH said means "Actions are according to intentions, and everyone will get what was intended ..."; (2) Tasmiyah (reciting bismillah); the Prophet Muhammad PBUH said: "No prayer is accepted without ablution and no ablution is accepted without mentioning Allah's name"; (3) Rinsing the inner mouth and sniffing water and blowing it once; (4) Washing the face once, ranging of a head of hair growth until the end of the beard, while the width of the face is between the left and right ear; (5) Passing wet fingers into the beard; (6) Washing both the arms including the elbows once; (7) Rubbing the hair once using wet hand; (8) Wiping both ears at once; (9) Washing both the feet once up to and including the ankles; (10) Passing wet fingers between fingers and toes; (11) Wudlu is done systematically.

Sunnah (optional) acts that can be done in wudlu are: (1) Rinsing the mouth, rubbing the teeth with a miswak; (2) Washing both the hands at the beginning of wudlu; (3) Rubbing the head of those who do not have long and thick hair; (4) Washing three times; (5) Reciting $d u^{\prime} a$ after wudlu which means "I bear witness that none has the right to be worshipped but Allah alone, Who has no partner; and I bear witness that Muhammad is His slave and His Messenger except that all eight doors of Paradise are opened for him, and he can enter into it through whichever one he pleases." (6) Offering two-rakaat prayer after wudlu.

The water required for wudlu is only holy and purifying water including rainwater, objects whose origin is water such as snow and dew, spring, well water, sea water, Zam-zam water, ajin water (water that has changed its characteristics), the water that has been mixed with excrement, but does not change its taste, color and smell, musta'mal water (water that has been used), water that has been warmed or heated. 
Sharia means the moral code and religious law which are charged to the Muslims to live the relationship with God and relationship with fellow human beings. A good wudlu is the one performed by not only washing part of the body, but also presenting the mind and heart that purifying parts of the body by water is a means to get inner purity. If this is done truly and sincerely for God, then it can abort sins.

Raga (the body) is observable in nature of wadhag (materialism). In the wadhag, human needs food, drink, air, and sunlight. Things included as the wadhag body are brain, heart, veins, nerves, blood and so on. If one part does not function, then health will be disrupted and the wadhag body will be damaged. For example, if the heart is experiencing restless or emotion, then someone will be easier to get disease and stress. So, the wadhag body needs to be maintained so as not susceptible to illness.

In this modern era, many ways can be done by humans to keep the wadhag body stay good and healthy by improving diet and nutrition or exercising according to the body condition. Older people, in regulating food nutrition, in general have to reduce foods that contain cholesterol such as meat, avoid foods that are too salty, and better eat lots of vegetables and fruits and prefer to consume drinking water. It is also better to work out by strolling or riding a bike on a regular basis. Moreover, if a Muslim has just had intercourse with his wife, or teenage gets a wet dream, they must perform a complete bath (ghusl) in preparation for formal prayers. This is also true for the Muslim. Thus, sêmbah raga is the first level in the worship to God and water is a means of ablution in preparation for this type of worship.

Almost all religions perform ablution because it basically makes a life worth living and cleanses the body of all the dirt on the body. Cleanliness can make the body healthy, and health will drain the power. Therefore, it can be concluded that purifying the body has benefits for health, fitness and diligence, and eliminates unpleasant smells.
Based on the above description, it can be concluded that sembah raga is the worship to God with emphasis on bodily movement behavior, or physical deeds (Ardani, 1995:56). In this stanza, there is an utterance 'magang laku' which means the human must have a long life journey or a spiritual life, as an actor who undergoes the early stages of an ascetic life. Asceticism in this sense does not have to be alone, meditating in a cave or sacred places, but trying to get closer to Allah. The utterance 'kang wus lumrah limang wêktu' means that the worship must be conducted in accordance with the requirement, i.e. five times a day.

The five-time worship, in the religion of Islam, is known as salat fardlu (obligatory prayers-fajr, dohr, asr, maghreb, and isha), which must be performed by meeting all the requirements and pillars (waktu wataking wêwaton). This worship must be done by every Muslim during his/her life. The implementation of this five-time worship is performing obligatory/ ritual prayers in the determined times including fajr (4:25 am), dohr (11:40 am), asr (15:00 pm), maghreb (17:30 pm), and isha (18:45 pm).

What is designated as a legal subject or mukallaf (the one charged with responding to and abided by the legislative commands) includes: (1) a person has received the message of Islam; (2) sane (healthy mind, not crazy or in the waking state); (3) baligh, i.e. the one who reaches the age of fifteen (15) lunar years, or has had a wet dream (for men), or has already married and menstruation for women. Meanwhile, the conditions of salat that must be met by someone who will perform salat are: confidence of the time of worship; facing the qibla; covering the awrah: the awrah of a man refers to the part of the body from the navel to the knees, while a woman should cover her entire body excluding her face and her hands to the wrist; clean and neat clothes: applies both to men and women; and the place of worship should be clean.

The steps in performing salat are: (1) Reciting takbiratul-ihram (saying Allahu Akbar in the first 
standing position while raising hands to the ears until the fingers almost touch the bottom of the earlobe, then it is sunnah to recite the du'a iftitah; (2) Reciting Fatihah, then it is recommended to recite other surah in the first and second rakaat; (3) Ruku' or bowing approximately ninety degrees; (4) Standing again (i'tidal); (5) Sujud (prostration), i.e. putting forehead and palms on the ground while reciting tasbih; (6) Sitting (between two prostrations); (7) Second prostration and reciting tasbih again as in the first prostration. If a prayer is performed only two rakaat like in the fajr prayer or sunnah prayer, then it ends up by saying salaam-Assalamu'alaikum warahmatullahi wabarakatuh-and then looks over your left shoulder and then the right one.

The implicature of this speech, especially in case of sêmbah raga, is although emphasizing more on bodily motions, it does not mean ignoring the spiritual aspect since someone who is practicing, in addition to presenting a set of physical movements, he/she also presents a set of spiritual aspects to rise to a higher spiritual stage. In short it can be said that when someone does a sembah (prayer), not only his/her soul that must be clean from evil desires, but the body should also avoid dirt. Therefore, to purify the body should be in accordance with the exemplified guidelines.

Ing uni-uni durung

Sinarawung wulang kang sinêrung

Lagi iki bangsa kas ngêtokkên anggit

Mintokkên kawignyanipun

Saréngaté élok-élok

'In the past'

'It has not been introduced the secret teachings'

'Only this time, there is a group who earnestly puts out their ideas'

'Demonstrate their skills

'In a strange way'

(Speech 3, source: R.Ng. Satyapranawa, and KRT. Sarjana Darmasarkara, 2000).

Speech at this Canto of Gambuh (speech 3) can be interpreted as follows. In the past, the Islamic scholars generally did not give supernatural or confidential teachings. However, in the next development, when this Tembang Gambuh was written, it was stated that at this time there were scholars who issued certain theories or doctrines to show versatilities in strange behaviors. This phenomena can be seen on the utterance 'saréngaté élok-élok'. In recent time, for instance, there is a group of people who perform ritual prayers (salat) using Javanese or Indonesian language, whereas they embrace Islam. This teaching is clearly contrary to the teachings of Islam, or not in accordance with the Sunnah of the Prophet, which is thus also not justified by the author of the tembang gambuh.

The implicature of the speech above is that in doing religious practices, someone must obey the valid law/regulation. Worship, for example, cannot be done using their own ways, but must be in accordance with the guideline.

Samêngko sêmbah kalbu

Yèn lumintu uga dadi laku

Laku agung kang kagungan Narapati

Patitis têtêsing kawruh

Mêruhi marang kang momong

Now it is about the heart's worship'

'If done regularly, it can be your conduct'

'A supreme conduct which has narapati'

'When a knowledge has been dominated by the right'

'It will show you the one who nurture this'

(Speech 4, source: R.Ng. Satyapranawa, and KRT. Sarjana Darmasarkara, 2000).

The outstanding utterances in this Canto of Gambuh above (speech 4) are "samêngko sêmbah kalbu, yèn lumintu uga dadi laku”. Sêmbah kalbu or called sêmbah cipta implies ideas, imagination, hope, or desire stored in the heart. Therefore, sêmbah cipta/kalbu in this case is referred as to worship by the heart.

Worship by the heart is to worship God with an emphasis on the role of heart. This worship, as well as sembah raga (worship by the body) should be conducted continuously on a regular basis to 
guide the actor/doer to a destination (yèn lumintu uga dadi laku).

The utterance pratitis têtêping kawruh mêruhi marang kang momong can be interpreted as a very long and not easily-passed journey taken by a sufi (mystic) in drawing near to God. However, for those who are able to master of the knowledge concerning such a journey and then practice it diligently and steadfastly, then they will be able to arrive at the destination and get to know the 'teacher'. Teacher in this sense is the one who nurtures those people, and guard and keep an eye on them (mêruhi marang kang momong).

Based on the utterances in the worship by the body and worship by the heart, it can be briefly said that the core of worship by the body emphasizes the use of water to wash away dirt and unclean things, while the core of worship by heart emphasizes the restraint on evil desires, and remove sin and stains which cause a variety of trespasses.

According to Nashr, the heart worship is done gradually starting from taqwa (piety), repent, wara'/syubhat, to stoic or patient (in Ardani, 1995:72). The description of these four stages are as follows: (1) Taqwa (piety), which means obeying rules and laws set by Allah; (2) Taubat (Repent), which means if someone has violated the rules and laws, then he/she should repent by fully intending not repeat violations and earnestly feel deterrent; (3) Wara /syubhat, which means if a person repents for reasons of neglecting or forgetting, committing sins, or being arrogant, as soon as possible he/she begs for forgiveness and is then be careful in dealing with what is halal (lawful), haram (unlawful) and syubhat (doubtful), then tries to stay away from something clearly unclean; (4) stoic or patient, which means being stoic in undergoing this life, patient in receiving various trials without complaints and restlessness, patient in obeying Allah (swt).

The implicature of speech in this stanza is self-restraint on evil desires by drawing closer to God. This can be done by way of remembrance of the oneness of God, for example, by looking at certain signs like gray hair, blurred eyes, old age, and that we all will be burned, sooner or later.

Suciné tanpa banyu

Mung nyênyuda mring hardaning kalbu

Pambukané: tata, titi, ngati-ati

Atêtêp, talatèn, atul

Tuladhan marang waspaos

'Self-purification cannot be performed by using water'

'But by reducing your heart ruthlessness'

'The beginning (of the process) should be done systematically, carefully, cautiously'

'Stoically, determinedly, and loyally'

'This is an example towards the vigilance'

(Speech 5, source: R.Ng. Satyapranawa, and KRT. Sarjana Darmasarkara, 2000).

The utterances in this stanza have very a great significance, marked by the provision mentioned including tata, titi, ngati-ati, atêtêp, têlatèn, atul (systematic, cautious, careful, stoic, painstaking, and loyal). Someone is going to have a brilliant future insight in dealing with the public, both worldly and spiritually. To get through the creation of such an insight, it needs training to master the moral to be implemented and beneficial to mankind.

The Mangkunagara IV'a speech "suciné tanpa banyu, mung nyênyuda mring hardaning kalbu" shows that the way to purify one's soul is no longer using water like that used in wudlu before body worship, but only to reduce, prevent or restrain the evil desires. Mind, as the source of all physical acts, shall be restrained or controlled so that it produces virtue. If someone always thinks of material/property, then his/her mind certainly thinks of how, at any time, to earn money and to get rich and richer. But on the contrary, the mind always thinks about how to make himself useful to people, then what he/she thinks and manifests is definitely actions needed by people, such as providing assistance in the forms of thought/opinion, being kind to people, helping people and so on. 
The implicature of this speech is as follows. The word "tata" (systematic) is usually associated with the word orderly, meaning that a person's activity must be done according to the same place and time. To achieve maximum results, it needs discipline and perseverance. The word "ngati-ati" (careful) has an implicature that when a person performs an activity carefully and cautiously, then he/she will get results in line with her/his expectation. The word "tetep" (stoic) means if a person has defined his/her goal clearly, then he/ she will be confident to step up to that goal. In the process, if experiencing problems, he/she will not change the direction and not easily discouraged or get bored. The principle of this speech is keep moving forward, never give up.

The implicature of the word "têtêg" (determined) is when someone faces difficulties and obstacles, he/she is not easy to give up. Whatever the difficulties are, he/she remains steadfast, sure, until the goal is achieved, and can be accounted for in the front of both humans and God. The word "têlatèn" (painstaking) means that if a person, in doing his/her activity/work, experiences difficulties or obstacles, he/she should not get bored easily and despair quickly, but should be eager to deal with it, be stoic to face it, persevere, persist, then try to find a solution so that the results can be still achieved in accordance with the intention. The word "atul" (loyal) means that if a person has got used to make all his/her activity in line the six words (utterances) above, then how difficult the job he/she can definitely overcome it.

At the end of the stanza, KGPAA Mangkunagara IV gave a guideline or advice to do so that people are cautious in dealing with all activities in life.

\section{Samêngko kang tinutur \\ Sêmbah katri kang sayêkti katur \\ Mring Hyang Sukma sukmanên saari-ari Arahên dipun kacakup \\ Sêmbah ing jiwa sutèngong \\ 'Now I will talk about' \\ 'The third worship as mentioned before'}

'Towards the Hyang Sukma who make you live every day'

'Try to achieve'

' 'This worship by the soul, my son'

(Speech 6, source: R.Ng. Satyapranawa, and KRT. Sarjana Darmasarkara, 2000).

The outstanding utterances in this stanza (speech 6) are "sêmbah katri kang sayêkti katur, mring Hyang Sukma sukmanèn saariari". Worship by the soul (suksma) should be always performed every day, and should be pursued so that all this worship can be achieved. The soul's worship means worship to Hyang Suksma (Allah) by prioritizing the role of smooth and deep soul, and internalizing it thoroughly pervasively, relentlessly or continuously every day. In this Mangkunagara IV's teaching of worship, worship by the soul is the one which has the most important position. Therefore, in this soul's worship, people attempt to emphasize the charging of all spirit aspects by way of zikir "remembrance", i.e. contemplating for drawing closer to Allah by means of emptying your mind of all existence except Allah.

The worship by the soul is performed by intending earnestly in the heart to pack/manage all aspects of life, then tied it tightly to be directed to the hoped goal without giving up what has been held at that time (Ardani, 1995:85). In the soul's worship, the purification can be done by means of awas (cautiousness) and éling/émut (consciousness). Cautiousness means being wary of the state along the soul/inner journey, do not be lost in direction towards something which is not good (misleading) or be cautious, while consciousness means being aware of the lofty ideals, which are fused with Hyang Suksma.

Usually, the word éling is specifically associated with a phrase 'sangkan paraning dumadi' which means that humans should always remember or be aware of its origin. In this sense, humans come from God, someday they will return to Him. Human life in this world is only temporary, therefore, while living in this world, humans must prepare themselves to be summoned 
by the Lord one day (passed away). The provisions or preparations to be made during life should refer to the oneness of God and also bring prosperity for themselves and others (righteous deeds). According to Suwardi Endraswara (2006:36-37), éling (being mindful) (1) leads life to focus on and not only look for sparkle and glitzy things, (2) foster self-awareness, and (3) direct people to conduct for the benefit of others.

The implicature of this speech is that someone, for still alive, must remember God Almighty in a sense to draw closer to Him. At this level, people have to think much of the afterlife, how to obey God by performing worship and avoiding His prohibitions. For believers, this understanding is identical to someone's duties in implementing the concept of 'amar maruf nahi mungkar' (enjoin good, forbid evil). The example of enjoining good is obeying Allah like conducting worship, loving to help people, providing convenience to someone and so on. Forbidding evil includes the following examples hurting others, slandering and so on.

Yèku wênganing kalbu

Kabukané kang wêngku-winêngku

Wêwangkoné wis kawêngku nèng sirèki

Nging sira uga kawêngku

Mring kang pindha kartika byor

'So that your heart reveals'

'The revelation of the controlling and the controlled'

'The territory has now been controlled in yourself'

'But yourself is also controlled'

'By the one shining like a star'

(Speech 7, source: R.Ng. Satyapranawa, and KRT. Sarjana Darmasarkara, 2000).

The utterances 'kabukané kang wêngkuwinêngku, wêwangkoné wis kawêngku nèng sirèku' and 'nging sira uga kawêngku serta mring kang pindha kartika byor' in this Canto of Gambuh (speech 7) can be interpreted as follows. When someone's mind has been opened or his/ her attitude has been mature, he/she will feel and see the One who controls and is controlled. A person will be aware of the law of karma, the law of action and reaction, or everything else will be reciprocal. At this level, someone starts to absorb the meaning of life in his/her heart. In relation to this sense, this concept is likely in line with the golden adage 'love your neighbor like thyself', meaning that if someone expects to be loved by someone else, then she/she must love someone else, too. Moreover, if someone does not want to be hurt, then do not hurt others. Therefore, do good to others, then others will do good to ourselves.

The implicature of speech in this stanza is as follows. Humans will get something in accordance with what they do, any righteous or evil deeds and 'amal (practices) will definitely get rewarded. In this case, a person who makes a lot of devout practices and earnestly performs worship, he/she would get rewards and paradise in the hereafter. On the contrary, someone who commits sins or disobey God would receive punishment and hell is his/her place.

\section{Samêngko ingsun tutur}

Gantya sêmbah ingkang kaping catur

Sêmbah rasa karasa rosing dumadi

Dadiné wis tanpa tuduh

Mung kalawan kasing batos

'Now, I say to you'

'Step up to the fourth worship'

'The worship by the sense which is the essence of life'

'There is no longer guideline'

'But only (using) the inner power'

(Speech 8, source: R.Ng. Satyapranawa, and KRT. Sarjana Darmasarkara, 2000).

The utterances sêmbah rasa karasa wosing dumadi in the Canto of Gambuh in this stanza (speech 8) can be interpreted as follows. This worship only uses sense as its essential basis, meaning it internalizes/feels the essence of the life of the universal creatures. While the heart worship implies the use of heart and the soul's worship implies the use of soul or spirit, the sense implies 
the use of inner spirit core or têlênging kalbu (the deepest part of heart).

Worship by the sense is the last worship, i.e. the existence which becomes a sign of achieving the lofty goal, because it is melted together in a life which controls and pervades the universe. This stanza is emphasized by a speech 'dadiné wis tanpa tuduh, mung kalawan kasing batos' which can be interpreted that sense is the guidance of all things in human life and its supporter is tranquility. This level can be said to be a journey toward the last goal in life. If this tranquility is instantly lost, it would result in the loss of awareness of the primary goal, causing this goal failed. Therefore, during stepping toward this final destination, it is necessary to arm with tranquility. In addition to being useful to maintain the safety of this process, it is also to prevent any confronting obstacles along the way, which ranges from the simple and easy to the difficult and heavy ones (R.Ng. Satyapranawa and KRT Sarjana Darmasarkara, 2000:254).

To perform worship by the sense, people no longer need the instruction and guidance of a teacher like the third worship, but it must be done independently with his own inner power. At this level, a person has to have spiritual maturity, therefore it is quite an expert in this worship. To do that, it takes courage and determination, without relying on others. Inner clarity is the main capital. In performing this worship, which is done without the guidance of a teacher, a person can be said to receive the grace or guidance from Allah. Whoever gets this special guidance (inspiration) has had a remarkable ability to cultivate the science of mind/inner knowledge and quickly prepare all aspects of the mind to get rid himself of all things except Allah. Such a person is called the sêpuh/pintêr person (mature mind and heart). $\mathrm{He} / \mathrm{she}$ is not affected by evil desires and wary of joining two elements-the will of God and the will of the servant (Ardani, 1995:96-97).

In harmony with this understanding, KGPAA Mangkunagara IV also gives a lesson that reads mangka nadyan tuwa pikun yèn tan mikani rasa, yêkti sêpi asêpa lir sêpah samun which means that even though people have been very old, if not heartless, they are really empty, no essence or benefit in their lives. Javanese people generally live according to Javanese culture. In this case, they make sense as the core of their spiritual practices. Utterances should be delivered with a sense, solving a case should be done with a sense, meaning that sense cannot be left behind. If the Western nations decide a case using the mind/ ratio, Javanese people use sense to decorate their moral attitudes. But now, it turns out that both the Western and Eastern people make a decision on a case based on the evidence and witnesses who can accurately be accounted for the truth.

The implicature of speech in this stanza is drawing closer to Lord cannot be delegated to others, but rather come from ourselves. This is in accordance with human's sensitivity of sense.

\section{CONCLUSION}

Based on the study of the meaning of sembah mentioned in the texts of Tembang Gambuh above, there are four types of sembah (worship) someone must do to draw closer to Allah (swt), which are body's worship, mind' worship, spirit's worship, and sense's worship. Worship by the body implies the need for health; (B) worship by the mind implies the need for mind treatment by feeding mind with real lessons such as science, art and culture, the experience of life; (C) worship by the soul/spirit implies the soul treatment by improving credence to the God Almighty by way of embracing religion; (D) worship by the sense implies the sense treatment which means that the final goal in life is about feeling, to feel, and be felt. When all these types of worship have been practiced, someone succeeds to draw closer to Allah (swt).

\section{REFERENCES}

Any, Anjar. (2001). Menyingkap Sêrat Wédotomo. Semarang: Aneka Ilmu.

Ardani, Moh. (1995). Al Qur'an dan Sufisme 
Mangkunagara IV (Studi Serat-Serat Piwulang). Yogyakarta: Dana Bhakti Wakaf.

Bratasiswara, Harmanto R. (2000). Bauwarna Adat Tata Cara Jawa. Jakarta: Yayasan Suryasumirat.

Endraswara, Suwardi. (2006). Falsafah Hidup Jawa. Yogyakarta: Penerbit Cakrawala.

(2006). Budi Pekerti Jawa Tuntunan Luhur dari Budaya Adiluhung. Yogyakarta: Buana Pustaka.

Lubis, Hamid Hasan A. (1991). Analisis Wacana Pragmatik. Bandung: Penerbit Angkasa.

Munandar, Aris. (2013). "Pemakaian Bahasa Jawa dalam Situasi Kontak Bahasa di Daerah Istimewa Yogyakarta”. Jurnal Humaniora. Vol. 25, No. 1,
92-102.

Pemberton, John. (1994). "Jawa" on the Subject of "Java. Translated by Hartono Hadikusumo. Yogyakarta: Mata Bangsa

Satyapranawa, R.Ng. dan Sarjana Darmasarkara, KRT. (2000). Bahasan dan Wawasan atas Serat Wédhatama Karya KGPAA Mangkunagara IV. Surakarta: Reksa Pustaka Mangkunagaran.

Simuh. (2002). Sufisme Jawa Transformasi Tasawuf Islam ke Mistik Jawa. Yogyakarta: Bentang Budaya.

Sutopo, HB. (2002 dan 2006). Metodologi Penelitian Kualitatif. Surakarta: Sebelas Maret University Press. 